\title{
Pharmacists as Care Providers for Stroke Patients: A Systematic Review*
}

\author{
Jade E. Basaraba, Michelle Picard, Kirsten George-Phillips, Tania Mysak
}

\begin{abstract}
Background: Pharmacists have become an integral member of the multidisciplinary team providing clinical patient care in various healthcare settings. Although evidence supporting their role in the care of patients with other disease states is well-established, minimal literature has been published evaluating pharmacist interventions in stroke patients. The purpose of this systematic review is to summarize the evidence evaluating the impact of pharmacist interventions on stroke patient outcomes. Methods: Study abstracts and full-text articles evaluating the impact of a pharmacist intervention on outcomes in patients with an acute stroke/transient ischemic attack (TIA) or a history of an acute stroke/TIA were identified and a qualitative analysis performed. Results: A total of 20 abstracts and full-text studies were included. The included studies provided evidence supporting pharmacist interventions in multiple settings, including emergency departments, inpatient, outpatient, and community pharmacy settings. In a significant proportion of the studies, pharmacist care was collaborative with other healthcare professionals. Some of the pharmacist interventions included participation in a stroke response team, assessment for thrombolytic use, medication reconciliation, participation in patient rounds, identification and resolution of drug therapy problems, risk-factor reduction, and patient education. Pharmacist involvement was associated with increased use of evidence-based therapies, medication adherence, risk-factor target achievement, and maintenance of health-related quality of life. Conclusions: Available evidence suggests that a variety of pharmacist interventions can have a positive impact on stroke patient outcomes. Pharmacists should be considered an integral member of the stroke patient care team.
\end{abstract}

RÉSUMÉ: Revue systématique du rôle des pharmaciens à titre de prestataires de soins dans le cas de patients victimes d'AVC. Contexte: Les pharmaciens font désormais partie intégrante des équipes multidisciplinaires procurant des soins aux patients, et ce, dans plusieurs établissements de soins de santé. Bien que des données probantes aient souligné leur rôle dans les soins apportés aux patients atteints d'un certain nombre d'états pathologiques, on recense peu d'études ayant évalué leurs interventions dans le cas de patients victimes d'AVC. L'objectif de la présente revue systématique est donc de résumer les données probantes ayant évalué l'impact des interventions de pharmaciens en ce qui regarde l'évolution de l'état de santé de patients victimes d'AVC. Méthodes: Dans un premier temps, nous avons identifié des résumés d'articles ou des articles complets dont le but était d'évaluer l'impact des interventions de pharmaciens sur des patients victimes d'AVC aigus/d'accidents ischémiques transitoires (AIT) ou possédant des antécédents d'AVC aigus et d'AIT. Une fois cette étape terminée, nous avons mené une analyse qualitative. Résultats: Un total de 20 résumés et articles complets a été inclus. Ces publications ont fourni des données probantes justifiant les interventions de pharmaciens dans plusieurs contextes, notamment dans le cadre de services d'urgence, au moment de périodes d'hospitalisation, à l'occasion de consultations externes ou dans des pharmacies communautaires. Dans une part importante de ces publications, on a pu observer que les pharmaciens collaboraient avec les autres professionnels de la santé dans la prestation de soins. Au nombre de leurs interventions recensées, mentionnons les suivantes : participer à des équipes d'intervention en cas d'AVC ; évaluer de possibles traitements thrombolytiques ; effectuer un bilan comparatif de médicaments ; participer aux visites auprès des patients ; identifier des problèmes liés à des traitements médicamenteux et les résoudre ensuite ; réduire les facteurs de risque et sensibiliser les patients. Cette implication des pharmaciens a été associée à une utilisation accrue de traitements fondés sur des données probantes, à une meilleure adhésion à la médication, à l'atteinte d'objectifs en matière de facteurs de risque et au maintien d'une bonne qualité de vie en lien avec la santé. Conclusions: Il ressort des données disponibles qu'une foule d'interventions menées par des pharmaciens peuvent avoir un impact positif sur l'évolution de l'état de santé de patients victimes d'AVC. En cela, les pharmaciens devraient être considérés comme faisant partie intégrante des équipes devant les soigner.

Keywords: Pharmacist interventions, pharmacist, multidisciplinary team, stroke

doi:10.1017/cjn.2017.233

Can J Neurol Sci. 2018; 45: 49-55

\section{INTRODUCTION}

Stroke is associated with significant morbidity and mortality. In Canada, approximately 46,500 people are hospitalized for stroke each year. It is the third leading cause of death, a significant cause of long-term disability, and exacts a significant cost to the economy. In 2012, the estimated cost of stroke in Canada was $\$ 3.6$ billion. ${ }^{1}$ Interventions that reduce the risk of stroke and improve outcomes in stroke patients are certainly of great importance.

The pharmacist has become an integral member of the multidisciplinary team providing clinical patient care in various healthcare settings. A meta-analysis evaluated the effects of pharmacist interventions in outpatient, inpatient, and emergency department settings. There was improvement in control of modifiable risk factors (blood pressure, cholesterol, hemoglobin $\mathrm{A}_{1 \mathrm{C}}\left[\mathrm{HbA}_{1 \mathrm{C}}\right]$, and blood glucose) and reduced hospitalizations and mortality. Safety

From the Faculty of Pharmacy and Pharmaceutical Sciences, University of Alberta, Edmonton, Alberta, Canada (JEB, MP, KGP, TM); Pharmacy Services, Alberta Health Services, Edmonton, Alberta, Canada (JEB, KGP, TM); Pharmacy Services, Alberta Health Services, Grande Prairie, Alberta, Canada (MP).

*The copyright line has been added. An erratum notice detailing this change was also published (DOI: 10.1017/cjn.2018.1).

Received November 29, 2016. Final Revisions Submitted May 11, 2017. Date of ACCEPTANCE May 27, 2017.

Correspondence to: Jade E. Basaraba, Pharmacy Services, 0G1.01 WMC, 8440-112 Street, Edmonton. Alberta, Canada, T6G 2B7. Email: jade.basaraba@ahs.ca 
outcomes included a reduction in adverse drug events and medication errors. $^{2}$ It is reasonable to infer that pharmacist interventions may benefit patients with cerebrovascular disease. However, minimal literature has been published evaluating the role of the pharmacist in caring for this population. The objective of the present systematic review was to summarize the available evidence evaluating the impact of pharmacist interventions on outcomes in stroke patients.

\section{MethodS}

\section{Literature Search}

A systematic search was performed using the following databases: Embase (1974 to March of 2015), International Pharmaceutical Abstracts (1970 to January of 2014), Medline (1948 to March of 2015), and Medline In-Process \& Other Non-Indexed Citations (1948 to March of 2015). Disease-related search and MeSH terms included: transient ischemic attack, stroke, cerebral infarction, cerebrovascular accident, brain ischemia, ischemic stroke, cerebral hemorrhage, hemorrhagic stroke, and intracranial hemorrhage. Provider-related terms included: pharmacist, pharmacy student, and pharmacy resident. No limits were applied.

\section{Study Selection}

Studies were identified and duplicates removed. One author (JB) independently screened all of the titles and abstracts, identifying relevant articles for potential inclusion. Two authors (JB and MP) independently reviewed all the remaining abstracts and full-text articles (if available) for eligibility. Discrepancies were resolved by reviewer discussion. If consensus could not be reached, two of the authors (TM and KGP) were consulted. To be eligible, the abstracts/articles had to contain an intervention by a pharmacist, pharmacy resident, or pharmacy student, and the study population had to comprise patients with an acute stroke or TIA or a history of stroke or TIA. Studies where a portion of the population had an acute stroke or TIA or a history of a stroke or TIA were included if the results pertaining to that population were reported separately. Studies were excluded if: they were not written in English; when the pharmacist intervention was inconsistent, not clearly defined, or limited to drug distribution; if the article was a review, case report, or descriptive study; or where no objective outcomes were reported. Studies in which the main intervention was anticoagulation management were also excluded, as this area of pharmacy practice is well-established in previous literature.

\section{Data Extraction}

Two authors (JB and MP) independently performed data extraction using a standardized data collection form. The following data were collected from each abstract or full-text article: (1) study characteristics (including study design, sample size, duration of follow-up); (2) patient care setting (including location and patient population); and (3) characteristics of provided care (including collaboration, degree of patient interaction, mode of patient interaction, hours of service, type of intervention, and provision of follow-up). All study outcomes were recorded.

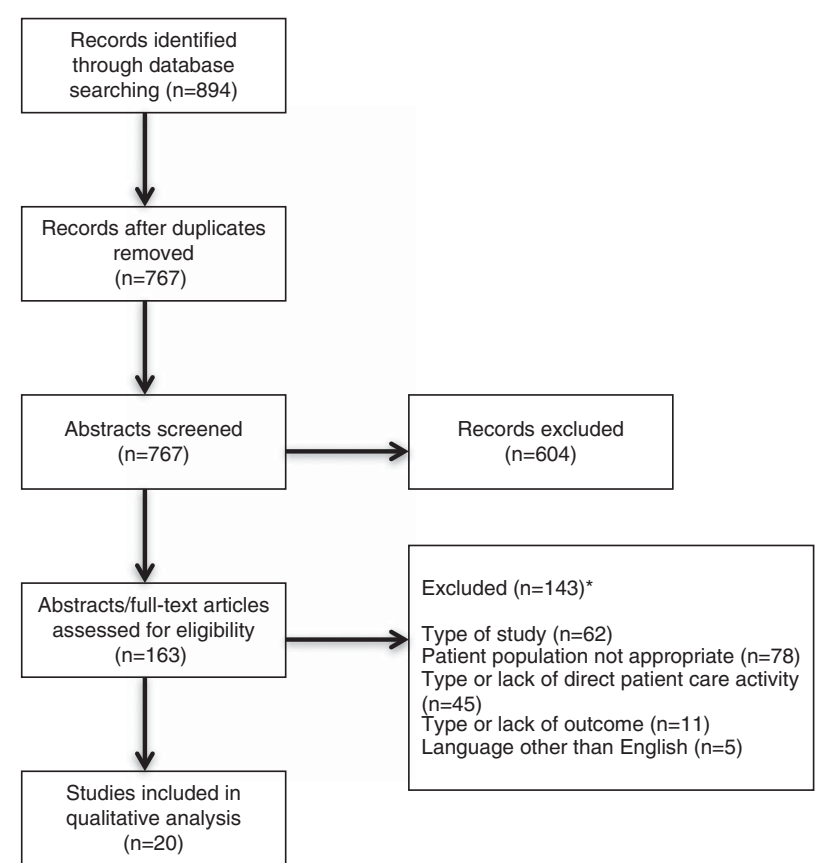

Figure 1: Study flow diagram. *More than one reason of exclusion could be selected for each study.

\section{Data Analysis}

A qualitative analysis was performed. The results are presented in a descriptive manner. A risk-of-bias assessment was not completed because of a lack of randomized trials and the limited number of full-text articles.

\section{RESULTS}

A total of 894 articles were identified from the literature search, 20 of which were included in this systematic review (Figure 1). A total of 10 were published as full text and the remainder only as abstracts. The included studies consisted of four randomized controlled trials, one nonrandomized controlled trial, nine prospective observational studies, and six retrospective observational studies. Seven of the studies included patient-important outcomes such as patient satisfaction, adherence to or independence with medication, health-related quality of life (HRQoL), and readmission rates. The remainder (13) looked at such surrogate outcomes as number of drug therapy problems, changes in blood pressure or lipid panels, or medication prescription rates. The most common direct patient care activity implemented was medication counseling. While nine additional studies were included initially, they were removed after further discussion, as the intervention provided by the pharmacist within the team was unclear. $^{3-11}$ The characteristics of the included studies are outlined in Table 1.

\section{Emergency Department}

One abstract (Brandon et al. ${ }^{12}$ ) described pharmacist participation with stroke patients in the emergency department (ED). It demonstrated that addition of a pharmacist to the stroke pager team, as well as participation in assessment, dose verification, and 
Table 1: Characteristics of included studies

\begin{tabular}{|c|c|c|c|}
\hline $\begin{array}{l}\text { Study population } \\
\text { First author, year of publication } \\
\text { Study design }\end{array}$ & $\begin{array}{l}\text { Number of } \\
\text { patients }\end{array}$ & Direct patient care activity & Outcome(s) measured \\
\hline \multicolumn{4}{|l|}{ Emergency department } \\
\hline $\begin{array}{l}\text { Acute stroke patients who are candidates for thrombolysis }{ }^{12} \\
\text { Brandon, } 2013 \\
\text { Prospective observational }\end{array}$ & Unknown & $\begin{array}{l}\text { Stroke response team } \\
\text { Thrombolytic dose calculation/verification } \\
\text { Thrombolytic preparation } \\
\text { Thrombolytic assessment } \\
\text { Patient/family medication education }\end{array}$ & Decision-to-needle time \\
\hline \multicolumn{4}{|l|}{ Inpatient } \\
\hline $\begin{array}{l}\text { Acute TIA/stroke patients taking at least two medications } \\
\quad \text { during hospital stay and at discharge }{ }^{13^{*}} \\
\text { Hohmann, } 2012 \\
\text { Prospective observational }\end{array}$ & 156 & $\begin{array}{l}\text { Drug-related problems identification and } \\
\text { resolution } \\
\text { Medication history and/or reconciliation } \\
\text { Monitoring of drug therapy } \\
\text { Patient assessment } \\
\text { Recommendations }\end{array}$ & $\begin{array}{l}\text { Percentage of patients who experienced a } \\
\text { drug-related problem (DRP) } \\
\text { Percentage of pharmacist interventions } \\
\text { accepted by the physicians }\end{array}$ \\
\hline $\begin{array}{l}\text { Acute stroke patients admitted to a stroke unit }{ }^{14} \\
\text { Hohmann, } 2010 \\
\text { Prospective observational }\end{array}$ & 250 & DRP identification and resolution & $\begin{array}{l}\text { DRPs identified } \\
\text { Percentage of DRPs resolved by pharmacist }\end{array}$ \\
\hline $\begin{array}{l}\text { Ischemic stroke patients }{ }^{15^{*}} \\
\text { Khalil, } 2014 \\
\text { Retrospective observational }\end{array}$ & 124 & $\begin{array}{l}\text { Medication history and reconciliation } \\
\text { Medication management review }\end{array}$ & $\begin{array}{l}\text { Percentage of patients discharged on } \\
\text { - lipid lowering therapy } \\
\text { - antihypertensives } \\
\text { - antithrombotics }\end{array}$ \\
\hline $\begin{array}{l}\text { Patients admitted to the stroke unit }{ }^{16} \\
\text { Barnett, } 2013 \\
\text { Prospective observational }\end{array}$ & 93 & $\begin{array}{l}\text { Medication counseling } \\
\text { Telephone referral to community pharmacy } \\
\text { Referral letter for community medication follow } \\
\text { up given to patient }\end{array}$ & $\begin{array}{l}\text { Postdischarge use of outpatient medication } \\
\text { adherence service }\end{array}$ \\
\hline $\begin{array}{l}\text { Acute stroke/TIA patients }{ }^{17^{*}} \\
\text { Hedegaard, } 2014 \\
\text { Randomized controlled trial }\end{array}$ & 203 & $\begin{array}{l}\text { Focused medication review } \\
\text { Motivational interview approached consultation } \\
\text { Three follow-up telephone calls over } 6 \text { months }\end{array}$ & $\begin{array}{l}\text { Medication possession ratio of antiplatelets, } \\
\text { anticoagulants, and statins } 1 \text { year after } \\
\text { hospitalization }\end{array}$ \\
\hline $\begin{array}{l}\text { Acute TIA/stroke patients taking at least two medications } \\
\quad \text { during hospital stay and at discharge }{ }^{18^{*}} \\
\text { Hohmann, } 2013 \\
\text { Prospective observational }\end{array}$ & 310 & $\begin{array}{l}\text { Communication with } \mathrm{HCP} \\
\text { Medication history and/or reconciliation }\end{array}$ & $\begin{array}{l}\text { Medication adherence to entire regimen at } \\
3 \text { months } \\
\text { Medication adherence to antithrombotics at } \\
3 \text { months } \\
\text { Medication adherence to statins at } 3 \text { months }\end{array}$ \\
\hline $\begin{array}{l}\text { Acute stroke patients } \\
\text { Tsai, } 2012 \\
\text { Retrospective observational }\end{array}$ & 648 & $\begin{array}{l}\text { Participation in stroke team } \\
\text { Recommendations }\end{array}$ & $\begin{array}{l}\text { Thrombolytic administration } \\
\text { Early antithrombotic use } \\
\text { Discharge antithrombotic use } \\
\text { Antithrombotic use for atrial fibrillation } \\
\text { Lipid-lowering therapy use }\end{array}$ \\
\hline $\begin{array}{l}\text { Stroke patients admitted to a rehabilitation hospital } \\
\text { Sreenivasan, } 2012 \\
\text { Retrospective observational }\end{array}$ & $116^{\dagger}$ & Patient education & Evaluation of educational sessions \\
\hline $\begin{array}{l}\text { Acute stroke patients } \\
\text { Scott, } 1989 \\
\text { Prospective observational }\end{array}$ & Unknown & Patient education & Independence with medications \\
\hline \multicolumn{4}{|l|}{ Outpatient } \\
\hline $\begin{array}{l}\text { Patients with a previous TIA/stroke attending a stroke } \\
\text { prevention clinic }{ }^{22^{*}} \\
\text { Lindblad, } 2008 \\
\text { Retrospective observational }\end{array}$ & $153^{\ddagger}$ & $\begin{array}{l}\text { Care plan development } \\
\text { Communication with HCP } \\
\text { DRP identification and resolution } \\
\text { Medication history and/or reconciliation } \\
\text { Monitoring of drug therapy } \\
\text { Patient assessment } \\
\text { Patient education } \\
\text { Recommendations } \\
\text { Risk-factor reduction }\end{array}$ & $\begin{array}{l}\text { Targeted outcomes per intervention } \\
\text { Physician acceptance of pharmacist } \\
\text { suggestions }\end{array}$ \\
\hline $\begin{array}{l}\text { Outpatients with recent minor ischemic stroke or transient } \\
\text { ischemic attack }{ }^{23 *} \\
\text { McAlister, } 2014 \\
\text { Randomized controlled trial }\end{array}$ & 279 & $\begin{array}{l}\text { Monthly clinic follow up visits x } 6 \text { months } \\
\text { Provided lifestyle advice } \\
\text { Monitored blood pressure and LDL level } \\
\text { Initiated or titrated antihypertensive and/or lipid- } \\
\text { lowering therapy }\end{array}$ & $\begin{array}{l}\text { Proportion of participants who attained } \\
\text { optimal blood pressure and fasting LDL }\end{array}$ \\
\hline $\begin{array}{l}\text { Stroke outpatients who had visited clinics at a hospital } \\
\text { regularly for more than } 12 \text { months }{ }^{24 *} \\
\text { Chiu, } 2008 \\
\text { Randomized controlled trial }\end{array}$ & 160 & $\begin{array}{l}\text { Risk-factor reduction } \\
\text { Patient education }\end{array}$ & $\begin{array}{l}\text { Change in blood pressure, lipid profile, and } \\
\text { fasting blood glucose } \\
\text { Proportion of patients with satisfactory } \\
\text { management of blood pressure, } \\
\text { dyslipidemia, and diabetes }\end{array}$ \\
\hline
\end{tabular}


Table 1. Continued

\begin{tabular}{|c|c|c|c|}
\hline $\begin{array}{l}\text { Study population } \\
\text { First author, year of publication } \\
\text { Study design }\end{array}$ & $\begin{array}{l}\text { Number of } \\
\text { patients }\end{array}$ & Direct patient care activity & Outcome(s) measured \\
\hline $\begin{array}{l}\text { Patients with a history of stroke } \mathrm{e}^{25} \\
\text { Nguyen, } 2011 \\
\text { Randomized controlled trial }\end{array}$ & 30 & $\begin{array}{l}\text { Care plan development } \\
\text { Communication with HCP } \\
\text { Patient education } \\
\text { Patient assessment } \\
\text { Recommendations } \\
\text { Risk-factor reduction }\end{array}$ & $\begin{array}{l}\text { Patient adherence to all medications } \\
\text { (according to pharmacy refill records) } \\
\text { Patient adherence to antithrombotics } \\
\text { (according to pharmacy refill records) } \\
\text { Patient achievement of blood pressure goals } \\
\text { Patient achievement of LDL goals } \\
\text { Patient achievement of blood glucose control } \\
\text { goals }\end{array}$ \\
\hline $\begin{array}{l}\text { Patients attending a stroke bridge clinic } \\
\text { Hooker, } 2012 \\
\text { Retrospective observational }\end{array}$ & Unknown & $\begin{array}{l}\text { Care plan development } \\
\text { Communication with } \mathrm{HCP} \\
\text { Medication history and/or reconciliation } \\
\text { Patient education } \\
\text { Risk-factor reduction }\end{array}$ & Readmission rates \\
\hline $\begin{array}{l}\text { Newly diagnosed stroke/TIA patients following hospital } \\
\quad \text { admission } \\
\text { Bruner, } 2012 \\
\text { Prospective observational }\end{array}$ & 72 & $\begin{array}{l}\text { DRP identification and resolution } \\
\text { Patient education }\end{array}$ & $\begin{array}{l}\text { Average pharmacist interventions per patient } \\
\text { 30-day readmission rates }\end{array}$ \\
\hline $\begin{array}{l}\text { Stroke patients with a need for medication education }{ }^{28} \\
\text { Lee, } 2004 \\
\text { Prospective observational }\end{array}$ & 22 & Patient education & Change in accuracy of patient knowledge \\
\hline \multicolumn{4}{|l|}{ Community pharmacy } \\
\hline $\begin{array}{l}\text { Patients with a TIA/ischemic stroke with Barthel index }>30 \text { at } \\
\text { time of discharge, now living at home } \text { (9* }^{*} \\
\text { Hohmann, } 2009 \\
\text { Nonrandomized controlled trial }\end{array}$ & 255 & $\begin{array}{l}\text { Communication with } \mathrm{HCP} \\
\text { Patient education } \\
\text { Patient assessment } \\
\text { Recommendations } \\
\text { Risk-factor reduction }\end{array}$ & $\begin{array}{l}\text { Change in health-related quality of life } \\
\text { Use of appropriate secondary prevention with } \\
\text { antithrombotics } \\
\text { Patient satisfaction }\end{array}$ \\
\hline $\begin{array}{l}\text { Patients with a history of stroke with a prescription for } \\
\text { ticlopidine } \\
\text { Fincham, } 2000 \\
\text { Prospective observational }\end{array}$ & 659 & $\begin{array}{l}\text { Monitoring of drug therapy } \\
\text { Patient education }\end{array}$ & Number of days off from refill date \\
\hline \multicolumn{4}{|l|}{ Long-term care } \\
\hline $\begin{array}{l}\text { Patients admitted to } \mathrm{LTC}^{31^{*}} \\
\text { Horning, } 2007 \\
\text { Retrospective observational }\end{array}$ & $104^{\S}$ & Recommendations & Adherence to clinical practice guidelines \\
\hline
\end{tabular}

$\mathrm{DRP}=$ drug-related problem; $\mathrm{HCP}=$ healthcare provider; $\mathrm{LDL}=$ low-density lipoprotein; $\mathrm{LTC}=$ long-term care, $\mathrm{TIA}=$ transient ischemic attack.

${ }^{*}$ Full-text article. ${ }^{\dagger}$ Number of evaluations. ${ }^{\ddagger}$ Number of patient encounters. ${ }^{\S}$ Number of stroke patients.

patient education, resulted in a reduction of decision-to-needle thrombolytic administration times.

\section{Inpatient Setting}

Nine studies involved a pharmacist practicing in an inpatient setting. ${ }^{13-21}$ Hohmann et al. ${ }^{13}$ demonstrated that a pharmacist completing medication reconciliation and participating in stroke team rounds resulted in identification of drug therapy problems in $68 \%$ of the patients, with an average of 1.8 problems per patient. In an another abstract by Hohmann et al., ${ }^{14}$ the stroke unit pharmacist identified an average of 1.9 drug therapy problems per patient and resolved over $95 \%$ of the problems identified. Khalil et al. ${ }^{15}$ found that $83 \%$ of stroke inpatients who received a medication management review by a pharmacist were on antihypertensive agents, compared to $59 \%$ of patients not reviewed by a pharmacist $(p=0.005) ; 92 \%$ were on antithrombotic agents, in contrast to $77 \%$ of patients not reviewed by a pharmacist $(p=0.025)$; while the difference in percentage of patients who were on lipid-lowering agents between the two groups was not significant. Barnett et al. ${ }^{16}$ found that telephone referral from the hospital to a community pharmacist increased the proportion of patients receiving follow-up within 4 weeks of discharge from 1.5 to $32 \%$. Two studies evaluated the impact of pharmacist intervention on medication adherence postdischarge. Hedegaard et al. ${ }^{17}$ randomized TIA and stroke patients to a multifaceted intervention by a pharmacist compared to usual care (no pharmacist) and demonstrated no significant difference in adherence to or persistence with secondary stroke prevention medications. Conversely, Hohmann et al. ${ }^{18}$ found that a letter communicating medication changes sent from an inpatient pharmacist to a patient's primary care provider at hospital discharge after a stroke or TIA increased medication adherence from 83 to $91 \%$ at 3 months postdischarge $(p=0.01)$ when compared to the control group, who had medication lists included in the discharge letter by the neurologist, as before. Tsai et al. ${ }^{19}$ suggested that recommendations by clinical pharmacists improved stroke guideline performance indicators. Sreenivasan ${ }^{20}$ found that patient satisfaction with stroke educational sessions improved when an interdisciplinary team including pharmacists presented the program. Scott et al. $^{21}$ reported that a self-medication program that included pharmacist medication teaching resulted in $78.1 \%$ of stroke patients achieving independence with their medications. 


\section{Outpatient Setting}

Seven studies reported outcomes associated with pharmacist interventions in outpatient settings. ${ }^{22-28}$ Lindblad et al. ${ }^{22}$ found that a pharmacist in a stroke prevention clinic was able to make an average of 2.8 interventions per patient encounter. McAlister et al. ${ }^{23}$ compared pharmacist-led and nurse-led case management of stroke patients in a randomized controlled trial. The control group received monthly follow-up from a nurse, who provided lifestyle advice, measured blood pressure and lipid levels, and faxed the results to their primary care physician. Patients in the intervention group were managed by a pharmacist with prescribing authority, and they received the same follow-up as the control group, as well as initiation/titration of antihypertensives and/or lipid-lowering therapy. After 6 months, $43 \%$ of patients managed by a pharmacist met both systolic blood pressure and low-density lipoprotein (LDL) goals, and $31 \%$ of patients managed by a nurse met both goals (number needed to treat $=8$, $p=0.03)$. In another randomized controlled trial, Chiu et al. ${ }^{24}$ evaluated the effect of monthly pharmacist education compared with usual care on modifiable risk factors. In the pharmacist intervention group, there was no significant difference in blood glucose control at the end of the study, but $83 \%$ of patients had adequately controlled blood pressure (compared to $40 \%$ at baseline, $p \leq 0.001)$ and $40 \%$ of patients had adequately controlled lipids (compared to $13 \%$ at baseline, $p=0.01$ ). In contrast, the control group had nonsignificant differences in all three endpoints. Similarly, Nguyen et al. ${ }^{25}$ recruited patients from a stroke prevention clinic and randomized them to pharmacist intervention or usual care. The pharmacist intervention group received telephone follow-up at 3 and 6 months to evaluate medication adherence, provide education, and reassess stroke prevention goals. Patients in the pharmacist intervention group were more likely to achieve blood pressure, cholesterol, and blood glucose goals at 6 months than those in the control group, and these improvements were maintained at 1 year. Hooker et al. ${ }^{26}$ evaluated the impact of a stroke bridge clinic involving a pharmacist, nurse practitioner, and nurse navigator on hospital readmission rates. Patients visited the clinic a week after discharge for education on risk factors and stroke prevention, medication reconciliation, and individualized treatment plans. Hospital readmission rates decreased from 14.5 to $2.2 \%$. Similarly, Bruner et al. ${ }^{27}$ reviewed pharmacist participation in stroke clinics, addressing drug therapy problems and providing medication education, noting that the clinics had a positive effect on 30-day hospital readmission rates. Lee et al. ${ }^{28}$ found a non-statistically-significant improvement in patients' knowledge of their current drug therapy after pharmacist medication counseling.

\section{Community Pharmacy}

There were two studies ${ }^{29,30}$ conducted in a community pharmacy setting. Hohmann et al. ${ }^{29}$ evaluated the impact of pharmaceutical care on the HRQoL of patients with a TIA or stroke who were discharged home. The pharmacist provided medication reviews and education, and resolved drug therapy problems. HRQoL was assessed using a scale validated in stroke patients. In the pharmacist intervention group, HRQoL remained stable, with only one of the HRQoL scales significantly decreased from baseline; in contrast, the control group had decreases in seven of eight scales. Fincham et al. ${ }^{30}$ found that community pharmacist intervention reduced the average number of days patients were late for ticlopidine prescription pickup from 11 to 2 .

\section{Long-Term Care}

Only one study was performed in a long-term care setting. Horning et al. $^{31}$ found that the difference in stroke guideline adherence between patients receiving active pharmacist disease state management consultation services compared to traditional pharmacist drug review was not statistically significant $(p=0.096)$.

\section{DISCUSSION}

Stroke patients interact with healthcare providers at many points throughout the course of their disease management. Diagnosis is often made in the ED, patients are admitted to acute-care hospitals, and, following discharge, stroke outpatient clinics assist patients with transition to the community and with chronic disease management. In the community, stroke patients seek medication and health-related advice from their primary care providers and may also require care in a long-term care facility. Our systematic review provides evidence that stroke patients benefit from pharmacist interventions in multiple care settings.

The available full-text studies suggest that pharmacists can positively impact stroke patient care in inpatient and outpatient settings with increased use of evidence-based therapies, medication adherence, risk-factor target achievement, and maintenance of HRQoL. The best available evidence demonstrates improvement in surrogate endpoints, and the cumulative evidence is positive for both surrogate and patient important outcomes. While providing fewer details, the reviewed abstracts largely support these studies and previously published literature supporting the value of pharmacists in several of these settings.

The acute treatment of stroke involves emergent administration of thrombolytic agents to reduce the risk of disability and death. ${ }^{32}$ Current guidelines recommend thrombolytic therapy within 4.5 hours of symptom onset, with a door-to-needle goal time of 60 minutes. ${ }^{33,34}$ In the ED, a pharmacist's assessment of patient eligibility and appropriateness of thrombolytic orders decreases time to administration, increases thrombolytic administration within the goal time, and improves order accuracy. Previous studies have shown that pharmacists in the ED add value through identification of medication errors, optimization of drug therapy, improvement of medication utilization, and increasing adherence to evidence-based practices. ${ }^{35-38}$ Our systematic review provides further evidence in support of pharmacists working within the ED, with an emphasis on the subset of patients with suspected or confirmed stroke.

Organized inpatient (stroke unit) care is described as "focusing of care for stroke patients in hospital under a multidisciplinary team who specialize in stroke management." ${ }^{39}$ When compared to care provided on a general ward, stroke unit care is associated with reductions in mortality, requirement for institutionalized care, and dependency. Pharmacists use their drug-focused therapeutic knowledge and medication management expertise to make valuable contributions to inpatient stroke care teams. A systematic review by Kaboli et al. ${ }^{40}$ discussed the benefits provided by clinical inpatient pharmacists, including less adverse drug events, increased accuracy of medication and allergy information, shorter lengths of stay, and reductions in hospital costs. Our systematic 
review further suggests that stroke patients may also benefit from having pharmacists integrated into inpatient stroke care in order to perform these evidence-based activities.

The period of time following hospital discharge can be difficult for the patients and their family members. Previous studies ${ }^{41-43}$ have demonstrated that pharmacist interventions in the outpatient setting are associated with significant improvements in management of modifiable risk factors, including reductions in $\mathrm{HbA}_{1 \mathrm{C}}$, blood pressure, and lipid levels. Our review found that outpatient pharmacists provide patient education and risk-factor modification, which results in reduced readmission and stroke recurrence rates. In conjunction with previous literature, the results from this systematic review provide support for pharmacists in the care of stroke patients in the outpatient setting.

Despite the available evidence, there remains a significant gap between research and practice in the care of stroke patients. Until recently, national stroke guidelines in North America ${ }^{44}$ did not include pharmacists on the list of recommended members of a stroke team. Interventions should be made in an effort to close this gap and ensure that pharmacists are active members of stroke teams in all settings.

\section{Limitations OF THE STUdY}

This review has limitations that warrant discussion. The quality and consistency of the research literature supporting integration of pharmacists into the stroke setting are limited. A search for unpublished literature was not performed. Studies with negative results may not be published, and this could lead to publication bias and an overestimation of the benefit of pharmacists in stroke care. Another limitation is that $50 \%$ of the studies included have not been published in full-text version, and abstracts provide limited information.

\section{CONCLUSIONS}

Pharmacists provide care to stroke patients in multiple settings. Supporting existing literature in other patient types, our review suggests that pharmacists improve the use of evidence-based therapies, reduce stroke risk through control of modifiable risk factors, and improve patient adherence in stroke-specific populations as well. Pharmacists should be considered an integral provider in the care of stroke patients.

\section{ACKNOWLEDGMENTS}

We are grateful to Drs. Brian Buck and Mark Makowsky for their thoughtful reviews of this manuscript.

\section{Statement of Authorship}

All four authors meet the criteria set out by the International Committee of Medical Journal Editors-namely, having had substantial contributions to the conception, design, analysis, and interpretation of the work; drafting and revising the paper; final approval of the attached version; and agreement to be accountable for all aspects of the work.

\section{Disclosures}

Jade E. Basaraba, Michelle Picard, Kirsten George-Phillips, and Tania Mysak hereby declare that they have no conflicts of interest to disclose.

\section{REFERENCES}

1. Canadian Stroke Best Practices. Important Findings Released Today at the Canadian Stroke Congress. Ottawa: Heart and Stroke Foundation of Canada; 2014. Available at: http://www.strokebestpractices. ca/index.php/news/the-5th-canadian-stroke-congress/.

2. Chisholm-Burns MA, Kim Lee J, Spivey CA, et al. US pharmacists' effect as team members on patient care: systematic review and meta-analysis. Med Care. 2010;48(10):923-33.

3. Bellolio MF, Finley JL, Flemming KD, et al. Implementation of a central page activation for acute ischemic strokes. Stroke. 2009; 40(4):E209.

4. Gosford CR, Hardeo S, Rizzo S, Fox S. Impact of door to alteplase (tPA) time with around the clock pharmacist response to code gray [abstract]. In: ASHP 2011 Midyear Clinical Meeting Professional Poster Abstracts; 2011 Dec 4-8; New Orleans, USA. 2012: A3092.

5. Murray S, Noviasky J. Emergency department pharmacist impact on tissue plasminogen activator (tPA) administration: time to administration and dose accuracy [abstract]. Presented at the ASHP Midyear Clinical Meeting; 2010; Anaheim, USA.

6. Pandya KA, Ruf KM, Winstead PS, Cook AM, Weant KA. Pharmacy resident participation with a 24-hour multidisciplinary stroke response team. Am J Health Syst Pharm. 2010;67(22): 1901-7.

7. Steiner NE, Wolber N, Robertson B, Rosenfield P, Paletz L. A team approach for improving door to needle time for IV t-PA in acute stroke [abstract]. In: Abstracts from the American Heart Association/American Stroke Association 2013 International Stroke Conference and Nursing Symposium; 2013 Feb 5-8; Honolulu, USA. Stroke. 2013;44:ATP362.

8. Garland J. Achieving target: stroke honor roll status through the utilization of 9 best practice strategies [abstract]. In: Abstracts from the American Heart Association/American Stroke Association 2013 International Stroke Conference and Nursing Symposium; 2013 Feb 5-8; Honolulu, USA. Stroke. 2013;44:AWP359.

9. Spokoyny I, Raman R, Ernstrom K, et al. Expedited code stroke protocol: an updated experience [abstract]. In: 2014 Annual Meeting of the American Academy of Neurology; 2014 Apr 26-May 3; Philadelphia, USA. Neurology. 2014;82(1):S35.002.

10. Sides EG, Zimmer LO, Wilson L, et al. Medication coaching program for patients with minor stroke or TIA: a pilot study. BMC Public Health. 2012;12:549.

11. McAlister FA, Grover S, Padwal RS, et al. Case management reduces global vascular risk after stroke: secondary results from the preventing recurrent vascular events and neurological worsening through intensive organized case-management randomized controlled trial. Am Heart J. 2014;168(6):924-30.

12. Brandon K, Kramer A, Mulawka C. Role of the clinical pharmacist in reducing decision-to-needle tPA times during code stroke in the emergency department. J Pharm Pract. 2013;26(3):200.

13. Hohmann C, Neumann-Haefelin T, Klotz JM, Freidank A, Radziwill R. Drug-related problems in patients with ischemic stroke in hospital. Int J Clin Pharm. 2012;34(6):828-31.

14. Hohmann C, Klotz JM, Radziwill R. Drug-related problems in patients at a stroke unit [abstract]. In: 19th European Stroke Conference Abstracts; 2010 May 25-28; Barcelona, Spain. Cerebrovasc Dis 2010;29(suppl 2):A220.

15. Khalil V, Li M, Hua QA. An audit of the pharmacological management of ischaemic stroke patients in a metropolitan Australian hospital. Int. J Clin Pharm. 2015 Feb37(1):8-11.

16. Barnett NL, Parmar P. Development and evaluation of hospital referrals for the new medicines service. Pharmacoepidemiol Drug Saf. 2013;22(6):671-2

17. Hedegaard U, Kjeldsen LJ, Pottegard A, Bak S, Hallas J. Multifaceted intervention including motivational interviewing to support medication adherence after stroke/transient ischemic attack: a randomized trial. Cerebrovasc Dis Extra. 2014:4(3):221-34.

18. Hohmann C, Neumann-Haefelin T, Klotz JM, Freidank A, Radziwill R. Adherence to hospital discharge medication in patients with ischemic stroke: a prospective, interventional 2-phase study. Stroke. 2013; 44(2):522-4. 
19. Tsai YJ, Leu WJ, Lin YM, Lu TH. Pharmacist's involvement in a multidisciplinary ischemic stroke team in and its associated cost avoidance [abstract]. In: ISPOR 5th Asia-Pacific Conference; 2012 Sep 2-4; Taipei, Taiwan. Value Health. 2012;15(7):A632.

20. Sreenivasan B. Inpatient stroke education in a rehabilitation hospital: patient evaluation [abstract]. In: 7th World Congress for Neurorehabilitation; 2012 May 16-19; Melbourne, Australia. Neurorehabil Neural Repair 2012;26(6):A321.

21. Scott JS, Sampson EF, D'Amato T. Self-medication in hospitalized stroke patients: effectiveness of medication counseling for right and left hemiplegics [abstract]. Presented at the Annual Meeting of the American Society of Health-System Pharmacists; 1989: P-32E.

22. Lindblad AJ, Howorko J. Integration of a pharmacist into a stroke prevention clinic team. Can J Hosp Pharm. 2008;61(6):431-6.

23. McAlister FA, Majumdar SR, Padwal RS, et al. Case management for blood pressure and lipid level control after minor stroke: PREVENTION randomized controlled trial. CMAJ. 2014; 186(8):577-84.

24. Chiu CC, Wu SS, Lee PY, Huang YC, Tan TY, Chang KC. Control of modifiable risk factors in ischemic stroke outpatients by pharmacist intervention: an equal allocation stratified randomized study. J Clin Pharm Ther. 2008;33(5):529-35.

25. Nguyen VV, Poon J, Tokuda L, Sayers J, Wallis R, Dergalust S. Pharmacist telephone interventions improve adherence to stroke preventive medications and reduce stroke risk factors: a randomized controlled trial [abstract]. In: International Stroke Conference and Nursing Symposium Poster Presentations presented at the International Stroke Conference; 2011 Feb 9-11; Los Angeles, USA. Stroke. 2011; 42:AWP302.

26. Hooker AF, Evans H. Does stroke bridge clinic reduce hospital readmission rates in patients who have suffered a stroke [abstract]. In: International Stroke Conference and Nursing Symposium Poster Abstracts; 2012 Feb 1-3; New Orleans, USA. Stroke. 2012;43:A2480.

27. Bruner L. Stroke bridge clinic: aiming at reduced readmissions for newly diagnosed stroke and complicated TIA patients [abstract]. Presented at the American Society of Health-System Pharmacists Summer Meeting; 2012 Jun 9-13; Baltimore, USA.

28. Lee J, Graham C, Silliman S, Merino-Juarez J. Evaluation of stroke patients' knowledge of their medications [abstract]. Presented at the ASHP Midyear Clinical Meeting; 2004 Dec 4-8; Orlando, USA: A121E.

29. Hohmann C, Klotz JM, Radziwill R, Jacobs AH, Kissel T. Pharmaceutical care for patients with ischemic stroke: improving the patients quality of life. Pharm World Sci. 2009;31(5):550-8.

30. Fincham JE, Wallace IA, Ivory A. Ticlopidine compliance enhancement: a community pharmacy based study. J Pharmacoepidemiol. 2000;8(1):51-66.

31. Horning KK, Hoehns JD, Doucette WR. Adherence to clinical practice guidelines for 7 chronic conditions in long-term-care patients who received pharmacist disease management services versus traditional drug regimen review. J Manag Care Pharm. 2007;13(1):28-36

32. Wardlaw JM, Murray V, Berge E, del Zoppo GJ. Thrombolysis for acute ischaemic stroke. Cochrane Database Syst Rev. 2009:(7): CD000213.

33. Jauch EC, Saver JL, Adams HP, et al. Guidelines for the early management of patients with acute ischemic stroke: a guideline for healthcare professionals from the American Heart Association/ American Stroke Association. Stroke. 2013;44(3):870-947.

34. Lindsay MP, Gubitz G, Bayley M, et al. Canadian Best Practice Recommendations for Stroke Care, Updated 2010. On behalf of the Canadian Stroke Strategy Best Practices and Standards Writing Group. Ottawa: Canadian Stroke Network; 2010. Available at: http://www.strokebestpractices.ca/index.php/news/ the-5th-canadian-stroke-congress/.

35. Marconi GP, Claudius I. Impact of an emergency department pharmacy on medication omission and delay. Pediatr Emerg Care. 2012;28(1):30-3

36. Patanwala AE, Sanders AB, Thomas MC, et al. A prospective, multicenter study of pharmacy activities resulting in medication error interception in the emergency department. Ann Emerg Med. 2012;59(5):369-73.

37. Abu-Ramaileh AM, Shane R, Churchill W, Steffenhagen A, Patka J, Rothschild JM. Evaluating and classifying pharmacists' quality interventions in the emergency department. Am J Health Syst Pharm. 2011:68(23):2271-5.

38. Cesarz JL, Steffenhagen AL, Svenson J, Hamedani AG. Emergency department discharge prescription interventions by emergency medicine pharmacists. Ann Emerg Med. 2013;61(2): 209-214.

39. Stroke Unit Trialists' Collaboration. Organised inpatient (stroke unit) care for stroke. Cochrane Database Syst Rev. 2007:(4):CD000197.

40. Kaboli PJ, Hoth Ab, McClimon BJ, Schnipper JL. Clinical pharmacists and inpatient medical care. Arch Intern Med. 2006;166(9): 955-64.

41. Stading J, Herrmann J, Walters R, Destache C, Chock A. Impact of pharmacist intervention on diabetes patients in an ambulatory setting. Diabetes Spectr. 2009;22(4):241-6; Available at: http:// spectrum.diabetesjournals.org/content/diaspect/22/4/241.full.pdf.

42. Sease JM, Franklin MA, Gerrald KR. Pharmacist management of patients with diabetes mellitus enrolled in a rural free clinic. Am J Health Syst Pharm. 2013;70(1):43-7.

43. Cording MA, Engelbrecht-Zadvomy EB, Pettit BJ, Eastham JH, Sandoval R. Development of a pharmacist-managed lipid clinic. Ann Pharmacother. 2002;36(5):892-904.

44. Casaubon LK, Suddes M, on behalf of the Acute Stroke Care Writing Group. Acute inpatient stroke care. In: Lindsay MP, Gubitz G, Bayley M, Phillips S editors Canadian Best Practice Recommendations for Stroke Care. Ottawa: Heart and Stroke Foundation of Canada, and the Canadian Stroke Network; 2013, Chap. 4. 